\title{
FEMINISTIČKA EPISTEMOLOGIJA: MOGUĆNOSTI POSTMODERNE FEMINISTIČKE TEORIJE STAJALIŠTA
}

\author{
Matko Krce-Ivančić
}

e-mail: matko.krce@gmail.com

\begin{abstract}
Sažetak
Ovaj članak istražuje mogućnosti postmoderne feminističke teorije stajališta kao jedne od prominentnijih feminističkih epistemologija. Iznosimo kontekst ove epistemologije, ističući važnost uspostave klasifikacije feminističke epistemologije koja prepoznaje postmodernizam kao integralni dio feminističkog empirizma $i$ feminističke teorije stajališta. Analiziramo osnovne teze feminističke teorije stajališta iz postmoderne perspektive, naglašavajući diskurzivnu narav društvene stvarnosti. Istražujemo političke mogućnosti ove epistemologije, ukazujući na potrebu drugačijeg shvaćanja političkog subjekta. Subjekt razumijevamo kao konstituiran, ali ne i determiniran, diskursom. Sukladno tome, propitujemo važnost zadržavanja različitih preddiskurzivnih uporišta feminističke politike. Postmoderno feminističko stajalište shvaćamo kao određenu vrstu diskursa, pri čemu ističemo manjkavost razlikovanja izmedu diskursa i materijalne stvarnosti. Razumijevanje vlastite društvene smještenosti identificiramo kao glavni cilj postmoderne feminističke teorije stajalista.
\end{abstract}

Ključne riječi: epistemologija, feminizam, postmodernizam, smještenost, feministička teorija stajališta

\section{UVOD ${ }^{1}$}

Feministička epistemologija jest socijalna epistemologija. U okviru socijalne epistemologije naglašava se da nije moguće izdvojiti znanje iz društvenih odnosa u kojima nastaje. Svako je znanje, dakle, društveno znanje. U ovom radu problematiziramo mogućnosti postmoderne feminističke teorije stajališta kao jedne od prominentnijih feminističkih epistemologija. Feministička epistemologija posvećena je razumijevanju uloge roda u proizvodnji i legitimiranju znanja, pri čemu se epistemologija obogaćuje spoznajama feminističke kritike društva. Ženska iskustva zauzimaju ključno mjesto u feminističkoj epistemologiji, no pokazalo se da nije posve jasno kako ih uklopiti u feminističku istraživačku praksu (Harding, 2004; Weedon, 1987). Feministička teorija stajališta predstavlja iznimno važnu epistemologiju jer razumije ženska iskustva kao središnje ishodište za izgradnju feminističkog spoznajnog stajališta i na taj način pokazuje značaj roda kao epistemološkog resursa.

1 Članak je nastao na temelju istoimenog diplomskog rada koji je autor obranio na Filozofskom fakultetu Sveučilišta u Zagrebu pod mentorstvom dr. sc. Branke Galić, red. prof. 
Prije svega iznosimo kontekst feminističke epistemologije, pri čemu se bavimo klasifikacijom feminističke epistemologije prema Sandri Harding (1999, 1987a), odnosno feminističkim empirizmom, feminističkom teorijom stajališta, tranzicijskim feminističkim epistemologijama i postmodernim feminističkim epistemologijama. Propitujemo razlikovanje tradicionalnog i feminističkog empirizma te identificiramo poveznice između feminističkog empirizma i feminističke teorije stajališta. Ukazujemo na radikalnost polaska od kritičke analize ženskih iskustava koju uvodi feministička teorija stajališta. Problematiziramo tranzicijske feminističke epistemologije, pitajući se može li se pozivanjem na tranzicijski karakter društva objasniti inovativnost epistemologija koje u takvom društvu nastaju. U okviru postmodernih feminističkih epistemologija bavimo se postmodernim odlikama feminističkog empirizma i feminističke teorije stajališta, primjećujući određene konvergencijske trendove između ovih epistemologija. Predlažemo alternativnu klasifikaciju feminističke epistemologije, smjerajući prvenstveno shvaćanju postmodernizma kao integralnog dijela feminističkog empirizma, a posebice feminističke teorije stajališta.

Zatim nudimo pogled na ključne postavke feminističke teorije stajališta iz postmoderne perspektive. $\mathrm{U}$ radu analiziramo mogućnosti i nudimo obrise nove, suvremene $\mathrm{i}$ postmoderne, feminističke teorije stajališta, odnosno ne radi se o pukom pregledu feminističke teorije stajališta. Posebnu pažnju posvećujemo konceptu smještenog znanja kojeg razvija Donna Haraway (1988), ističući kako je svako viđenje nužno utjelovljeno. Razmatramo njenu kritiku spoznajnog subjekta koji skriva vlastitu smještenost, tobože gledajući s pozicije izdvojene od društvenih odnosa. Navedeno autorica naziva „božjim trikom“, a budući da ovaj koncept smatramo važnim jer podsjeća kako je svaka epistemologija nužno socijalna, nastojimo ga dodatno pojasniti. Također, primjećujemo određenu nelagodnost feminističke teorije stajališta naspram diskurzivnosti vlastitih temelja koju donosi postmodernizam te je težimo razjasniti s ciljem mijenjanja uvriježenog uvjerenja prema kojem postmoderna teorija onemogućuje feminističko stajalište. Stoga analiziramo potrebu prominentnijih autorica za inzistiranjem na konceptima poput tjelesnih aspekata postojanja, prirode neovisne od diskursa, preddiskurzivne konkretne stvarnosti, materijalističkog momenta i sl. te promišljamo mogućnost postmoderne alternative. Tako problematiziramo shvaćanje prema kojem je društvena stvarnost diskurzivno omogućena, a feminističko stajalište izvor protuhegemonijskog diskursa. Nadalje, analiziramo argumente koje Harding (1991) iznosi u prilog epistemičkoj povlaštenosti feminističke teorije stajališta. Važno je pritom napomenuti da se ne upuštamo u puko shematsko iznošenje razloga privilegiranosti ove epistemologije, već tim razlozima pristupamo kritički, prvenstveno iz postmoderne perspektive. Sukladno tome, između ostalog, ukazujemo i na ostatke esencijalizma, ali i probleme s postojećom terminologijom prilikom proučavanja suvremenih odnosa moći u društvu.

Nakon toga istražujemo političke mogućnosti postmoderne feminističke teorije stajališta. Bavimo se feminističkom politikom iz postmoderne perspektive, polazeći od kritike uobičajenog razumijevanja subjekta u okviru predstavničke politike. Pozivamo se na shvaćanje politike prema Chantal Mouffe (1993), budući da njene uvide smatramo ne- 
izostavnima pri problematiziranju odnosa postmodernizma i feminizma. Naime, iznosimo autoričinu tezu prema kojoj feministička demokratska politika iziskuje napuštanje esencijalizma i njegovih izvedenica, odnosno humanizma, univerzalizma i racionalizma. Međutim, ovdje i odgovaramo na kritiku prema kojoj se postmoderna teorija napuštanjem ženske esencije odriče identiteta uopće. Naglašavamo kako se koncept identiteta može različito razumjeti, pri čemu objašnjavamo zašto pretpostavljanje identiteta kao gotove, „učvršćene“ odrednice, nije prihvatljivo postmodernizmu. Razmatramo kakvo shvaćanje politike odgovara postmodernoj feminističkoj teoriji stajališta te težimo pojasniti da postmodernizam ne dokida, već omogućuje teoriji stajališta svrsishodno bavljenje politikom. Analizirajući koncept „izdajničkih identiteta“, koji je osmislila Harding (1991), nudimo put prema kritici vlastite smještenosti, što postavljamo kao glavni cilj postmoderne teorije stajališta. U radu se pokazuje da postmodernizam omogućuje feminističkoj teoriji stajališta da izbjegne stranputice esencijalizma i ostvari svoje pune spoznajne i emancipatorne potencijale.

Naposljetku, kako bismo ukazali na neprimjerenost olakog odbacivanja postmoderne teorije podsjećamo na takozvanu „afera Sokal“ kao i na njene implikacije, imajući u vidu da atmosfera koju je „skandal“ proizveo negativno utječe na status postmodernizma uopće pa tako i postmodernih tendencija teorije stajališta.

\section{KONTEKST FEMINISTIČKE EPISTEMOLOGIJE}

Kada analizira feminističke epistemologije, Harding (1999, 1987a) razlikuje feministički empirizam, feminističku teoriju stajališta (engl. feminist standpoint theory), tranzicijske feminističke epistemologije i postmoderne feminističke epistemologije. Ono što karakterizira sve navedene epistemologije, a što je od iznimne važnosti za tematiku koju problematiziramo, jest da „svaka počinje izlaziti iz područja prosvjetiteljstva“ (Harding, 1999:82) s ciljem stvaranja prostora otvorenijeg za feminističke glasove.

\subsection{Feministički empirizam}

Kako bismo objasnili feministički empirizam kao epistemološku poziciju potrebno je prvo razjasniti što razlikuje navedeni pristup od tradicionalnog empirizma. Harding (1987a:183) ističe kako feministički empirizam nije ispravno poistovjetiti $s$ tradicionalnim empirizmom jer ima „radikalnu budućnost“ iz tri razloga. Navodimo mjesta razlikovanja između tradicionalnog i feminističkog empirizma koje autorica identificira, ali pozivamo čitatelje da obrate pozornost na izvjesnu kontradiktornost između ovih razilaženja epistemoloških putova.

Prvo, feministički empirizam ističe važnost konteksta znanstvenog otkrića. Navedeno se suprotstavlja pretpostavci tradicionalnog empirizma prema kojoj društveni identitet istraživača nema utjecaja na validnost znanstvenih nalaza. Feminističke empiričarke tvrde da će istraživačice vjerojatnije izbjeći utjecaj androcentrizma od muških znanstvenika, upravo stoga što su osjetljivije na predrasude prema ženama. Počinje se shvaćati da 
kanonska istraživanja nije proizvela bestjelesna norma empirizma, već stvarni istraživači, uglavnom klasno i rasno privilegirani muškarci (Harding, 1987a). Dakle, propituje se uvjerenje tradicionalnog empirizma o nevidljivom istraživaču koji pruža besprijekorne znanstvene nalaze.

Drugo, feministički empirizam odbacuje tvrdnju da se pukim pridržavanjem postojeće znanstvene metodologije može izbjeći androcentričnost znanosti. Naime, feminističke empiričarke podsjećaju da se hipoteze oblikuju u određenom društvenom kontekstu, odnosno predstavljaju interese istraživača koji su, kao što smo prethodno napomenuli, uglavnom dobrostojeći bijeli muškarci. Drugim riječima, „feministički empirizam tvrdi da androcentrična slika prirode i društvenog života proizlazi iz toga što muškarci provjeravaju samo hipoteze potaknute onim što muškarci nalaze problematičnim u svijetu oko njih" (Harding, 1987a:184). Dakle, strožim pridržavanjem znanstvene metodologije empirizma ne može se dokinuti androcentrizam. Upravo suprotno, time se osigurava dosljedna androcentričnost znanstvene zajednice.

Treće, feministički empirizam polazi od pretpostavke da je androcentrizam u znanstvenom radu prisutan isključivo u lošoj znanosti. Sukladno tome, navedeni se problemi mogu izbjeći strožim pridržavanjem metodoloških uputa empirizma. Drugim riječima, problem nije u normi koju uspostavlja empirizam nego u mainstream analizi koja se iz nekog razloga odmetnula od istinske znanosti (Harding, 1987a). Dakle, prema feminističkom empirizmu androcentrizam nije produkt znanosti, već istraživača koji vlastiti rad podmeće pod kategoriju znanosti. Stoga za loše nalaze nije ispravno kriviti znanost, nego ju je potrebno zazivati, budući da su oni očito produkt neznanstvenih istraživanja. Analizirajući tri izvora „radikalne budućnosti“ feminističkog empirizma, dojma smo kako se zapravo radi o svojevrsnim razvojnim etapama ove epistemologije, pri čemu se od zahtjeva za strožom primjenom znanstvenih kriterija, preko shvaćanja znanstvene metodologije kao društveno oblikovane, dolazi do potrebe kritičkog osvrta na odnos istraživača i znanstvenog rada. Stoga smatramo kako je razumijevanje androcentrične znanosti kao loše znanosti uputnije označiti kao nešto zajedničko, odnosno sjecište tradicionalnog i feminističkog empirizma, a ne kao mjesto razilaženja dviju epistemologija. Naime, i sama Harding (1987a:184) uviđa kontradiktornost kada tvrdi da „feminističke empiričarke često opominju istraživače u društvenim znanostima da prate postojeće istraživačke norme rigoroznije. $S$ druge strane, može se razumjeti da one tvrde kako je upravo precizno praćenje ovih normi ono što pridonosi androcentričnim istraživačkim rezultatima“. Štoviše, ako feminističke empiričarke ističu da iza znanstvenog rada stoji istraživač s pripadajućom društvenom smještenošću, malo je vjerojatno da će se tradicionalna metodologija i dalje shvaćati kao nedovoljno primijenjena datost. Iako nas autorica ostavlja zakinutima za detaljniju elaboraciju ove kontradiktornosti, smatramo kako upravo iz navedene situacije proizlazi njena potreba da uvede kategoriju tranzicijskih feminističkih epistemologija, kojima ćemo se kasnije baviti. Svejedno, uvjereni smo da su napori feminističkog empirizma prema propitivanju uloge istraživača i neutralnosti znanstvene metodologije od iznimne važnosti, a daljnju artikulaciju pronalaze u postmodernim tendencijama feminističke epistemologije. 


\subsection{Feministička teorija stajališta}

Feministička teorija stajališta predstavlja epistemologiju koja ženska iskustva razumijeva kao središnje empirijsko i teorijsko ishodište. Dakle, zahtijeva se odbacivanje pristupa pukog „dodavanja“ žena u znanstvena istraživanja, a naglašava potencijal ženskih iskustava. Naime, feminističke istraživačice prvotno su nastojale „dodati“ žene u vlastite analize i to, prema Harding (1987b), prije svega tri grupe žena: one aktivne u društvenim znanostima, one koje su doprinijele javnom životu koji su istraživači već proučavali te one koje su žrtve najistaknutijih oblika muške dominacije. Navedena je perspektiva manjkava iz razloga što prominentnije istraživačice u društvenim znanostima čine određenu skupinu žena koje su se uspjele othrvati iznimnom pritisku androcentrične znanstvene zajednice, odnosno neprestanom isključivanju ili barem revidiranju njihovih istraživanja kako bi odgovarala muškim predodžbama o društvu. Također, „dodavanje“ žena koje su se istaknule istraživanjem androcentričnih znanstvenih pitanja previđa potrebu identificiranja i proučavanja istraživačkih pitanja važnih prvenstveno ženama. Dakle, ženski doprinosi javnom životu žena naprosto se izostavljaju prilikom problematiziranja društvenih odnosa. Naposljetku, proučavanje žena isključivo kao žrtava različitih oblika nasilja počinjenih od strane muškaraca izostavlja aktivnu komponentu ženskog suprotstavljanja muškoj dominaciji koja je prisutna, ali uslijed shvaćanja žene kao prvenstveno pasivne ne dolazi dovoljno do izražaja (Harding, 1987b). Kada sagledamo navedena ograničenja, jasno je da „dodane“ skupine žena neodgovarajuće predstavljaju složena ženska iskustva prisutna u svakodnevnim društvenim odnosima.

Stoga, feministička teorija stajališta polazi od radikalno drugačijeg pristupa, utemeljujući vlastite epistemološke uvide na ženskim iskustvima. Dakle, ženska iskustva se ne „dodaju“, već se od njih polazi kako bi se izgradilo posebno, feminističko stajalište. Također, ne radi se o monolitnom ženskom iskustvu, već o ženskim iskustvima. Naime, kada smo odbacili ideju univerzalnog muškarca, „onda je 'muškarčeva' vječna družica - ‘žena' također nestala" (Harding, 1987b:7). Međutim, feministička teorija stajališta ne staje na tome, već tvrdi kako društvene znanosti moraju služiti ženama. Dakle, odbacuje se uloga svojevrsnog podilaženja muškarcima istraživanjem njihovih interesa te se počinje shvaćati kako su ženama potrebni odgovori na drugačija pitanja od onih koje postavljaju muškarci (Harding, 1987b). Izričito se zahtijeva da se znanstvenik i predmet istraživačkog interesa promatraju na istoj kritičkoj ravni, odnosno shvaćaju kao dio istraživačkog procesa u okviru metodologije. Ovo, kako ironično primjećuje Harding (1987b:9), „ne znači da se prva polovica istraživačkog elaborata treba baviti ispitivanjem duše“, ali znači kako je određeni stupanj refleksivnosti nezaobilazan ako od znanosti zahtijevamo objektivnije nalaze. Također, odbacuje se pretpostavka da su androcentrične pristranosti znanstvenih nalaza tek produkt nedovoljnog pridržavanja znanstvene norme. Drugim riječima, shvaća se kako se i loša znanost zapravo shvaća kao znanost, što može zvučati obeshrabrujuće, ali barem pruža uvid u realno stanje stvari i iziskuje promjenu razumijevanja znanosti kao ahistorijske panaceje ženskog pitanja. 
Dakle, proučavajući odlike feminističke teorije stajališta, ne možemo previdjeti nove uvide koje nam navedena epistemologija omogućuje. U okviru feminističke teorije stajališta novost zasigurno predstavlja izraženije shvaćanje da žena nije monolitni subjekt feminističke teorije. No, ideja izgradnje stajališta baziranog na iskustvima obespravljenih žena jest ono zaista drugačije u okviru ove epistemologije, a čime ćemo se detaljnije baviti kasnije u radu. S druge strane, primjećujemo i izvjesnu podudarnost između navedene epistemologije i feminističkog empirizma. Zahtjev za kritikom društvene smještenosti istraživača prisutan je i u feminističkom empirizmu uz razumijevanje znanstvene metodologije kao oblikovane određenim društvenim kontekstom. Navedene podudarnosti još jednom podsjećaju kako niti feministička teorija stajališta nije nastala u vakuumu ideja, već ima svoja izvorišta kojima je nužno oblikovana, gdje prominentno mjesto zasigurno zauzima i feministički empirizam. Štoviše, i sama Harding (1999:85) tvrdi da su teorije stajališta „svojevrsne analize i objašnjenja istraživanja feminističkih empiričarki“. Smatramo kako feministička teorija stajališta predstavlja nedvosmisleno prevladavanje i daljnji razvitak postmodernih tendencija unutar feminističkog empirizma, čime se ove dvije epistemologije jedna drugoj sve više približavaju.

\subsection{Tranzicijske feminističke epistemologije}

Upravo zbog teško uhvatljive razlike između feminističkog empirizma i feminističke teorije stajališta, Harding (1987a) smatra obje epistemologije tranzicijskim feminističkim epistemologijama. Ovdje se tranzicija shvaća kao napetost između epistemologije i znanosti, pri čemu autorica smatra kako je navedeno indikator napretka znanosti. Naime, ako je epistemologija u potpunom skladu sa znanošću, nalazimo se u hegemonijskoj situaciji, u kojoj se trebamo zapitati koja su znanja potisnuta uslijed takve epistemološko-znanstvene konstelacije. Primjerice, androcentrična epistemologija u kombinaciji s androcentričnim društvenim znanostima i biologijom usporila je razvoj feminizma, a žene učinila inferiornima (Harding, 1987a). Što se tiče suvremenosti, autorica smatra kako središnju poziciju u društvenim znanostima zauzimaju liberalizam i marksizam $s$ pripadajućom tradicijom androcentričnih autoriteta. U takvoj koncepciji feministički empirizam i feministička teorija stajališta predstavljaju alternativne pravce postojećem shvaćanju znanosti i epistemologije. Slažemo se da navedene epistemologije imaju snažan potencijal u redefiniranju znanosti, ali ne vidimo potrebu za korištenjem termina tranzicijske epistemologije. Naime, smatramo da alternative koje nude feministički empirizam i feministička teorija stajališta ne proizlaze iz tranzicijske naravi društva, već iz postmodernih mogućnosti ovih epistemologija.

\subsection{Postmoderne feminističke epistemologije}

Uz feministički empirizam, feminističku teoriju stajališta i tranzicijske feminističke epistemologije, Harding (1999, 1987a) problematizira i postmodernu feminističku epistemologiju, pri čemu zapravo analizira neke aspekte postmodernizma unutar feminističkog empirizma i feminističke teorije stajališta. Feministički empirizam vidi „kao nehotičan 
put k drukčijem idealnom spoznavatelju i idealu objektivnosti od prosvjetiteljskih" (Harding, 1999:85) te ističe „da je spoznajući subjekt feminističkog empirizma sukobljen s prosvjetiteljskim pretpostavkama. Žena znanstvenica ne može biti prosvjetiteljski transpovijesna, unitarno individualna" (Harding, 1999:84). S druge strane, navodi više postmodernističkih odlika feminističke teorije stajališta poput razumijevanja napretka znanosti kao društveno oblikovanog procesa, odbacivanja ahistorijskih načela istraživanja, zahtjeva za napuštanjem ideje o unitarnoj svijesti koja je zapravo muška svijest te dokidanja dihotomija moderne zapadne znanosti. Iako autorica na nekim mjestima ističe vrijednosti postmodernih tendencija, kao kada tvrdi da „naši feminizmi u ovome trenutku povijesti trebaju i prosvjetiteljske i postmoderne agende“ (Harding, 1999:90), često se može iščitati njezina izvjesna nelagoda od postmodernizma u feminističkoj epistemologiji. Ambivalentnost je posebice očita kada se postavlja pitanje političkog djelovanja žena gdje se, od težnje dijela postmodernih teoretičara prema savezništvu obespravljenih po različitim osnovama Harding (1987a:189) ograđuje, ističući: „ali preuranjeno je za žene da budu voljne odustati od onog što nikad nisu imale“, pri čemu u vidu ima epistemološko stajalište bazirano na iskustvima žena. Čini nam se da je glavni izvor tjeskobe od postmoderne teorije ovdje izazvan strahom od gubitka posebnog, ženskog političkog subjekta. Smatramo kako autorica nedovoljno razrađuje navedenu bojazan, iako je i mi smatramo jednom od ključnih prijepora prilikom rasprave o političkim mogućnostima postmoderne teorije stajališta te ćemo je u ovom radu nastojati pojasniti.

Sažimajući dojmove o autoričinoj elaboraciji feminističke epistemologije, smatramo tendencije postmodernizma i izvjesni tranzicijski karakter sastavnim dijelovima feminističkog empirizma i feminističke teorije stajališta, a ne zasebnim epistemologijama. Koristeći se klasifikacijom koja se sastoji iz podjele na dvije epistemologije, odnosno na feministički empirizam i feminističku teoriju stajališta, izbjegli bismo dojam da je postmodernizam nešto izvanjsko feminističkoj epistemologiji i otvoreno priznali doprinose postmodernizma ključnim postavkama feminističke teorije stajališta.

\section{KLJUČNE POSTAVKE FEMINISTIČKE TEORIJE STAJALIŠTA IZ POSTMODERNE PERSPEKTIVE}

\subsection{Donna Haraway i koncept smještenih znanja}

Doprinosi Donne Haraway feminističkoj teoriji stajališta odlikuju se problematiziranjem socijalnog konstruktivizma. Bell (2007:92) navodi kako najoštriji kritičari pogrešno doživljavaju Haraway kao „postmodernističku šaljivicu“ i svojim radom nastoji dokazati neutemeljenost ove kritike. Ovdje krećemo suprotnim smjerom i težimo radikalizirati postmoderne elemente u Harawayinom radu. Naravno, poznato nam je da i sama Haraway (1988:577) tvrdi: ,što dalje idem s opisivanjem radikalnog programa socijalnog konstruktivizma i određenog oblika postmodernizma, uparenog sa zajedljivim oruđima kritičkog diskursa u ljudskim znanostima, postajem nervoznija“ pa je stoga 
teško očekivati da bi ju se naše kritike dojmile. Međutim, smatramo da upravo nervoza izazvana postmodernizmom predstavlja poticaj na razvijanje koncepta smještenih znanja (engl. situated knowledges)

Razvijajući vlastite koncepte Haraway (1988) tvrdi da se istovremeno oslanja na dva kraja dihotomije, odnosno radikalni konstruktivizam i feministički kritički empirizam. Međutim, ubrzo shvaća kako je teško graditi teoriju na dva različita temelja te svoj rad počinje razumijevati kao redefiniciju metafore viđenja. Zalaže se za potrebu shvaćanja svakog viđenja kao nužno utjelovljenog. Navedeno zahtijeva dokidanje pogleda „od nigdje i svugdje“ koji ujedno ima moć da vidi i bude nevidljiv, odnosno „reprezentira izbjegavajući reprezentaciju“ (Haraway, 1988:581). Takvo izdizanje spoznajnog subjekta na poziciju koja tobože transcendira utjelovljenost i društvene odnose autorica naziva „božjim trikom“ koji opisuje kao mitsko viđenje. Ipak, bitno je pažljivo iščitati o čemu se zapravo radi. Naime, „božji trik“ jest mit budući da predstavlja krinku pomoću koje navodnom izdvojenošću iz odnosa moći osigurava spoznavatelju neometano upražnjavanje moći. Međutim, u ljudskoj svakodnevnici „božji trik“ postaje uobičajena praksa. Drugim riječima, mit strukturira svakodnevicu. Upravo stoga Haraway (1988) ističe potrebu utjelovljenosti viđenja koja uključuje naglašenu lokaliziranost i parcijalnost znanja, što rezultira konceptom smještenih znanja. Važnost navedenog za feminističku teoriju stajališta jest u tome što autorica naglašava potencijal viđenja iz društvene smještenosti obespravljenih žena. Međutim, tematici pristupa iznimno oprezno. Uviđa opasnost romantiziranja obespravljenih te ističe da "stajališta podjarmljenih nisu 'nevine' pozicije“ (Haraway, 1988:584). Upravo smještenost znanja omogućava odgovornost za ono što vidimo, a dokida lagodnost viđenja izdvojenog od društva. Također, mogućnost viđenja odozdo, sa stajališta obespravljenih, nije nešto što se lako stječe, čak i ako je sam spoznajni subjekt obespravljen. Štoviše, Haraway (1988:584) napominje: „kako vidjeti odozdo je problem koji zahtijeva barem onoliko vještine s tijelima i jezikom, s posredovanjima viđenja, koliko i 'najviše’ tehnoznanstvene vizualizacije“. Naposljetku, autorica naglašava da se ne radi o jednom feminističkom stajalištu, budući da postoji niz osi obespravljenosti, primjerice rasa, klasa i rod. Također, ne smatra da je moguće istovremeno biti obespravljen na sve postojeće načine te takvo što smatra iluzornom potragom za „punim“, odnosno totalnim, fetišiziranim subjektom. No, ističe „mogućnost mreža poveznica zvanih solidarnost u politici a dijeljeni razgovori u epistemologiji“ (Haraway, 1988:584). Dakako, koncept smještenih znanja nije imun na kritike pa tako Campbell (2004) zamjera Haraway jer ne nudi model pomoću kojeg bi se takve mreže uspostavile. Slažemo se da u radu nisu dostupni gotovi modeli umreženosti obespravljenosti, ali ovu kritiku smatramo problematičnom jer, paradoksalno, ne uvažava smještenost znanja. Naime, važnost parcijalnosti spoznaje naglašava se upravo zbog „poveznica i neočekivanih prolaza" (Haraway, 1988:590, kurziv dodan, op.a.) koje nam pružaju smještena znanja. Dakle, obespravljenost je uvijek određena kontekstom, a grandiozni model, koji bi nam obuhvaćajući sve osi obespravljenosti u punini njihove različitosti pružio univerzalan epistemološki vodič, zaista je teško zamisliti. 


\subsection{Nelagodnost diskurzivnosti temelja feminističke teorije stajališta}

Međutim, naši problemi $s$ Haraway (1988) počinju s njezinim specifičnim razumijevanjem svijeta koje povlači značajne posljedice po shvaćanje spola i roda. Naime, oslanjajući se na tradiciju ekofeminizma, Haraway (1988:593) tvrdi da je svijet iznimno aktivan subjekt koji posjeduje stanoviti „smisao za humor neugodan za humaniste i druge posvećene svijetu kao resursu“. Dakle, autorica kritizira shvaćanje svijeta kao svojevrsnog okvira unutar kojeg se nalaze pasivni objekti spremni za eksploataciju. Drugim riječima, svijet nije nešto pasivno, odnosno „sirovi materijal za humanizaciju“ u „logici kapitalističkog kolonijalizma“" (Haraway, 1988:592-593). Dodajemo kako smatramo da ovdje nije riječ o prvenstveno kapitalističkoj, već prosvjetiteljskoj tradiciji u kojoj se priroda konceptualizira tek kao nešto od instrumentalne važnosti. Svejedno, svakako se slažemo s kritikom prema kojoj prirodu nipošto ne smijemo shvaćati kao predmet bjesomučne eksploatacije, ali nismo skloni nadahnutijem viđenju svijeta kojeg nudi autorica. Naime, Haraway (1988:596) se zalaže za to da svijet razumijemo kao „lukavca $s$ kojim moramo naučiti razgovarati“, posebice sklonog različitim dosjetkama i ironiji. Smatramo da nema potrebe za karakteriziranjem svijeta kao „lukavog šaljivca“ kako bi se dokinule eksploatatorske prakse. Naime, svijet ne mora postati čovjekom da bismo prihvatili njegovu intrinzičnu vrijednost. Međutim, ovdje se zapravo radi o tome da autorica nastoji utvrditi karakter prirode koji je donekle neovisan od diskursa, budući da ga smatra neophodnim za feminizam. Navedeno se vidi kada ističe: „izgubiti autoritativno biološko poimanje spola, koje uspostavlja produktivne napetosti s rodom, čini se prevelikim gubitkom" (Haraway, 1988:591). Tako tijelo, kao i svijet, postaje aktivan subjekt, a ne puki resurs. $\mathrm{O}$ čemu se zapravo radi postaje očito tek u bilješkama na kraju teksta gdje Haraway (1988:599), komentirajući rad Evelyn Keller, tvrdi: „ona također inzistira na potrebi zadržavanja nekih nediksurzivnih temelja u 'spolu' i 'prirodi', možda ono što ja nazivam 'tijelom' i 'svijetom'“. Dakle, kada se zaviri iza metafora, vidimo da se radi o svojevrsnoj nelagodi od prihvaćanja diskurzivne konstituiranosti roda i napuštanja pozivanja na prirodu kao instance koja omogućava feminizam, a time i feminističku teoriju stajališta.

Međutim, Haraway ovdje nije sama. Nancy Hartsock (2004) preferira formulaciju „seksualna podjela rada“ umjesto „rodna podjela rada“ kako bi izbjegla svođenje podjele rada između žena i muškaraca na društvenu uvjetovanost. Naime, smatra važnim ,zadržati tjelesne aspekte postojanja - možda ih se i prečvrsto držati u naporu da ih sačuvamo od isparavanja u potpunosti“ (Hartsock, 2004:289). Međutim, ova linija argumentacije najbolje se može proučavati na primjeru Nancy Hirschmann (2004:317) koja otvoreno ističe da se zalaže za "novi način konceptualiziranja materijalističkih dimenzija iskustva koji bi mogao biti kompatibilniji s postmodernim pojmom diskurzivnosti“". Jasno implicirajući povezanost $s$ Hartsock, u nedostatku materijalnog aspekta ženskih iskustava vidi mogućnost isparavanja temelja feminističkog stajališta Hirschmann (2004:324). Štoviše, Hirschmann (2004:325) smatra da feminističko stajalište logički zavisi od „preddiskurzivne 'konkretne stvarnosti'“. Kako bi razriješila navedenu nedo- 
umicu, uvodi koncept materijalističkog momenta koji prema njenom mišljenju čini preddiskurzivnost prihvatljivom u okviru postmodernizma. Međutim, sam koncept je poprilično nejasno objašnjen pa tako autorica tvrdi da moment može potrajati kroz povijesne epohe, a istovremeno ljudskom umu biti gotovo neuhvatljiv. Materijalistički je moment svojevrsni ,figurativni 'moment' u vremenu gdje pojedinci vide da postojeći dominantni diskurs nije 'istinit" (Hirschmann, 2004:325). Drugim riječima, pojedinci na trenutak izlaze iz diskursa, shvaćaju pravo stanje stvari te se i prije nego što su to osvijestili vraćaju u diskurzivno satkane društvene odnose. Također, autorica tvrdi da koncept momenta preuzima iz postmoderne teorije, ali nažalost ne specificira izvore. Možda se ovdje radi o Foucaultovom interesu da objasni „kako se moglo dogoditi da se u nekim momentima i u nekim poretcima znanja javljaju grubi prekidi, ove naglosti evolucije, ove transformacije koje ne odgovaraju mirnoj i kontinuiranoj predodžbi koju obično imamo" (Foucault, 1994c:145-146, kurziv dodan, op.a.). Međutim, ovdje se problematizira kontingentnost diskursa, a ne spominje uspinjanje na stajalište izvan diskursa. No, ako odbacimo kompromisni materijalistički moment, isparavaju li temelji feminističke teorije stajališta?

Smatramo kako nema mjesta panici. Naime, prema Susan Hekman (1997) feminističku teoriju stajališta možemo shvaćati kao diskurs koji se suprotstavlja hegemonijskom diskursu. Tako se izbjegava potreba za materijalističkim momentima koji nam pružaju istinu, ali i pokazuje da feminističko stajalište nije logički ovisno o preddiskurzivnoj utemeljenosti ženskih iskustava. Štoviše, diskursi su „sui generis materijalne stvarnosti“ (Jäger, 2001:36), ništa manje stvarni od „preddiskurzivne 'konkretne stvarnosti'“ koju spominje Hirschmann (2004:325). Dakle, diskurs nije ono što se u tradiciji ortodoksnog marksizma shvaća kao lažna svijest, odnosno svojevrsna obmana koju treba odbaciti kako bismo napokon ostvarili pravednije društvene odnose. Upravo suprotno, sama je stvarnost diskurzivno proizvedena te su stoga pokušaji zadržavanja materijalističkih temelja stvarnijih od diskursa naprosto izlišni. Međutim, ovdje je bitno napomenuti kako diskurzivno polje nije iscrpljeno suprotnošću hegemonijskog i protuhegemonijskog diskursa, kao što se može dobiti dojam čitajući Hekman (1997). Situacija je mnogo kompleksnija, budući da su diskursi fragmentarniji i kontradiktorniji nego što se to obično misli te stoga „ne treba zamišljati svijet diskursa podijeljen između prihvaćenog i isključenog diskursa već kao mnoštvo diskurzivnih elemenata koji mogu djelovati u različitim strategijama" (Foucault, 1994b:70). Naime, Hekman (1997) govori o protuhegemonijskom diskursu feminističke teorije stajališta u jednini, dok se zapravo radi o različitim, čak i međusobno sukobljenim diskursima feminističkih teorija stajališta, budući da epistemologija koju problematiziramo nije monolitno polje. Naravno, smatramo to prednošću feminizma, ali i ističemo potrebu uvažavanja bogatstva feminizma prilikom istraživanja diskurzivnosti stajališta. Dakle, jasnim zahtjevom za shvaćanjem feminističkih stajališta kao diskurzivno utemeljenih izbjegavaju se različiti oblici pozivanja na istinsku stvarnost, ali i pribjegavanja biologiji. Tako se dokida i esencijalističko shvaćanje stajališta, „esencijalističko jer projicira značajke koje se razvijaju u historijski specifičnim društvenim uvjetima na sve žene i muškarce" (Fraser i Nicholson, 1999:30). Dakako, 
feministički naglasak na diskurzivnosti zahtijeva redefiniranje uobičajenog shvaćanja spola i roda. Prema općepoznatom udžbeničkom razlikovanju, spol je prirodna činjenica, odnosno nešto s čime se rodimo i ostaje netaknuto kulturom, a rod treba razumjeti kao ekspresiju spola u određenoj kulturi. Dakle, zapravo se ne radi niti o opreci prirode i kulture, budući da je rod kulturno posredovani spol. Nasuprot takvom shvaćanju, Judith Butler (2000:22) ističe da „rod nije kulturi ono što je spol prirodi; rod je također diskurzivno / kulturalno sredstvo kojim se 'spolna priroda' ili 'prirodni spol' proizvode i uspostavljaju kao 'preddiskurzivni', prethodeći kulturi“. Dakle, spolu se odriče odlika preddiskurzivnosti te ga se počinje shvaćati kao diskurzivnu konstrukciju, čime se dokida razlikovanje roda i spola. Sukladno tome, rod ne nastaje kao ekspresija spola u danom kulturnom kontekstu, već se uspostavlja kroz performativne činove, izvedbe i geste (Butler, 2000:137). Navedeno ima izraziti emancipatorni potencijal, budući da se ljudi napokon oslobađaju od biologije kao vjekovne sudbine, ali i postaju odgovorniji za svoje djelovanje. Uvažavajući doprinose postmoderne teorije, u ovom radu pokazujemo da epistemička produktivnost feminističke teorije stajališta ne zahtijeva preddiskurzivna uporišta i posve je održiva bez zazivanja bioloških temelja rodnih razlika.

\subsection{Sandra Harding i epistemička povlaštenost feminističke teorije stajališta}

Međutim, često se tvrdi kako izostaje objašnjenje zašto bismo uopće prihvatili epistemičku privilegiranost feminističke teorije stajališta (primjerice, Hekman, 1997). Međutim, Harding (1991:121-134) shematski navodi niz razloga zbog kojih je uputno dati prednost feminističkom stajalištu, pri čemu se referira na brojne teoretičarke feminističke epistemologije. Slažemo se sa Smith (1997) kada ističe kako Harding kroz svoj rad objedinjuje niz različitih autorica, potencirajući dojam jedinstva prilikom bavljenja feminističkom teorijom stajališta. Stoga je važno iz postmoderne optike sagledati razloge epistemičke povlaštenosti koje iznosi Harding, prilikom čega treba imati u vidu da se bavimo idejama niza autorica koje ne predstavljaju homogenu znanstvenu zajednicu posvećenu isključivo feminističkoj teoriji stajališta.

Prije svega, Harding (1991:128) tvrdi da je ,ženska perspektiva iz svakodnevnog života" te je stoga uputno polaziti od ženskih iskustava prilikom izgradnje stajališta. Ovdje se autorica poziva na rad Smith (2004) koja tvrdi da su žene zadužene za obavljanje konkretnih, svakodnevnih aktivnosti, primjerice pranje odjeće i brigu o bolesnima, a sve kako bi se muškarci mogli neometano baviti ozbiljnom, apstraktnom sociologijom. Dakle, dok je muškarac u konceptualnom stanju svijesti, žena „skrbi za logistiku njegova tjelesnog postojanja" (Smith, 2004:26), čime nastaje podjela na svijet konstruiran prema apstraktnim konceptima sociologije i svijet temeljen na svakodnevnim iskustvima. Sukladno tome, dolazi do diskrepancije između socioloških uvida i svakodnevnih iskustava ljudi. Upravo zbog toga Smith (2004) tvrdi kako koncepte u sociologiji treba graditi polazeći od ženskih iskustava, a ne od apstraktnih socioloških predstava o društvu. Problem je tim veći što su se ženski životi tradicionalno isključivali iz znanstvenih istraživanja, a njihovim bi se uključivanjem, prema Harding (1991:121-124), znatno 
reducirala iskrivljenost znanstvene spoznaje. Također, smatra kako su veća zastupljenost žena u visokom obrazovanju, društveni pokreti 1960-ih godina te brojni ekonomski, društveni i politički fenomeni konačno otvorili prostor za istraživanja koja polaze od ženskih života. Štoviše, uvjerena je da su žene uslijed obespravljenosti motivirane za poticanje društvene promjene, prilikom čega pričaju iz neistražene perspektive otpora muškoj opresiji (Harding, 1991:125-133). Osnovni prigovor koji možemo uputiti navedenom shvaćanju odnosi se na nedovoljno razlikovanje ženske i feminističke teorije stajališta, što otvara prostor esencijalizmu. Naime, autorica se pita „zašto je stajalište žena - ili feminizma - manje parcijalno ili iskrivljeno nego slika prirode i društvenih odnosa koja proizlazi iz konvencionalnog istraživanja?" (Harding, 1991:121, kurziv dodan, op.a.), poistovjećujući žensko i feminističko stajalište. Smatramo takvu neodređenost problematičnom jer prema našem razumijevanju iskustva obespravljenih žena pružaju polazište za izgradnju feminističkog stajališta. Dodatno, feministička teorija stajališta jest, kao i feminizam, istovremeno teorija i pokret, te je stoga eksplicitno politički nastrojena. Naime, žensko stajalište, prema shvaćanju njegove najpoznatije predstavnice Smith (1997:393), „uopće nije ista stvar i nema ništa s opravdavanjem feminističkog znanja“, već označava polazak od ženskih iskustava prilikom uspostavljanja kvalitetnije sociologije. Također, feministička teorija stajališta nije isto što i ženska perspektiva, nije naprosto ono što žene vide u svakodnevnom životu. Dakle, ne radi se o romantiziranom pogledu na ženska iskustva kao intrinzično epistemički privilegirana. Iako Harding (1991:121-134) napominje da sve žene nisu feministkinje, da ženska perspektiva nije automatski epistemički privilegirana te na nizu mjesta naglašava postojanje različitosti među ženama, često se poziva na koncepte koji vrlo teško mogu izbjeći optužbe za esencijalizam. Primjerice, ističe koncept „majčinskog mišljenja“ Sare Ruddick (1995), pri čemu složenost dječjeg života predstavlja transkulturnu činjenicu koja iziskuje majčinsku brigu, a na čijim se iskustvima onda može uspostaviti majčinsko mišljenje. Smatramo ovakvo shvaćanje složenosti kulturno oblikovanim, a samim time i majčinsko mišljenje postaje problematično jer se određeni društveni kontekst poopćava na sve kulture. Također, Harding (1991:121-122) iznosi potrebu prihvaćanja perspektive koju nam pružaju teorije o posebnoj ženskoj strukturi ličnosti, što prema našem mišljenju predstavlja pokušaj pronalaska čvrstog uporišta za feminističke argumente, ali sasvim sigurno završava u esencijaliziranom shvaćanju rodnih odnosa. Naime, naprosto nije moguće istovremeno izbjeći zamke esencijalizma i pozivati se na teorije o ženskoj strukturi ličnosti te se oslanjati na koncept majčinskog mišljenja. Harding (1999:90) tvrdi $\mathrm{da}$ „naši feminizmi u ovome trenutku povijesti trebaju i prosvjetiteljske i postmoderne agende", no ostaje nejasno kako te dvije agende pomiriti. Smatramo kako bi se navedeni problemi u argumentaciji mogli izbjeći da je autorica jasnije i konzistentnije odredila vlastitu poziciju naspram esencijalizma, kojeg ovaj rad jednoznačno odbacuje.

Nadalje, prema Harding (1991), posebna vrijednost ženskih iskustava očituje se u ženskom igranju uloge stranca u društvu gdje muškarci predstavljaju „urođenike“. Naime, stranac ima objektivniji uvid u društvene odnose jer je znatno manje uronjen u svakodnevnicu u kojoj se našao, a ljudi ga percipiraju kao osobu s kojom mogu otvorenije 
podijeliti vlastita iskustva. Navedene prednosti stranca, prema Patriciji Collins (2004), predstavljaju ključne odrednice statusa „autsajdera iznutra“ (engl. outsider within) koji je zbog svog specifičnog društvenog statusa spoznajno povlašten. Međutim, kako bi Harding (1991:131-132) u analizu unijela više osi obespravljenosti žena, ističe vrijednost razumijevanja marginaliziranosti prema bell hooks (1990:153), pri čemu margina predstavlja „lokaciju radikalne otvorenosti i mogućnosti“. Dakle, ovdje se margina ne shvaća kao mjesto opresije iz kojeg treba pobjeći u centar te što prije zaboraviti na vlastitu prošlost. Upravo suprotno, predlaže se politizacija iskustva marginaliziranosti, pri čemu margina postaje centar proizvodnje protuhegemonijskog diskursa (bell hooks, 1990:145-153). Međutim, smatramo ovakvo razumijevanje problematičnim jer suvremeni odnosi moći nadilaze podjelu na centar kao monolitnu utvrdu moći i marginu shvaćenu kao „jedno mjesto velikog Odbijanja - duša pobune“ (Foucault, 1994b:67). Naime, ako se složimo da je moć posvuda jer ima nebrojeno izvorišta, nije li marginu ispravnije nazivati „nijemo, ušutkano središte“ (Spivak, 2011:99)? Također, obespravljenost žena nije prisutna isključivo u prostoru margine, niti prestaje njenim napuštanjem. Opisujući vlastita iskustva s dolaskom na pretežito bjelačko sveučilište, bell hooks (1990:151) tvrdi: „napravljena sam 'Drugom' tamo u tom prostoru s njima“, iz čega se vidi njena daljnja marginaliziranost u samom centru. Stoga, smatramo da je potrebno ponovno promisliti klasičnu podjelu na centar i marginu te obespravljenost proučavati uvažavajući kapilarno ispoljavanje moći.

Naposljetku, Harding (1991:130-131) vidi epistemičku povlaštenost stajališta u ženskom dokidanju dihotomije kulture i prirode te niza podjela koje proizlaze iz nje, poput intelektualnog i emocionalnog rada. Ovdje se autorica poziva na Hartsock (2004) prema kojoj ženska iskustva kao što su rađanje, briga za djecu, menstruacija ili dojenje rezultiraju jedinstvom tijela i uma kakvo se ne može naći kod muškaraca. Međutim, izostaje genealoška analiza kategorija koje Hartsock (2004) koristi, kao što su majčinstvo i reprodukcija, nakon koje bi se utvrdila njihova eventualna kulturna univerzalnost. Naime, dojam kako se radi o nečemu usko povezanim s biološkim potrebama i reprodukcijom društva može navesti na olako poopćavanje analiziranih praksi (Fraser i Nicholson, 1999). Također, budući da se Hartsock (2004) snažno oslanja na Marxa, propušta uvidjeti da se obespravljenost žena ne odvija isključivo po klasnoj osi, što i sama ističe u svojim kasnijim osvrtima, pozivajući se na shvaćanje Marxa kao svojevrsnog protuprosvjetiteljskog mislioca na pomolu (Hartsock, 1997). Naravno, Marx se može tumačiti na različite načine, ali je potrebno analizirane dijelove sagledati u odnosu na cjelinu njegova rada. Sukladno tome, riječima da „priroda pojedinaca dakle zavisi od materijalnih uvjeta koji određuju njihovu proizvodnju" (Engels i Marx, prema Hartsock, 2004:286) ne treba pridavati značenje radikalne konstruktivističke pozicije kakvu nalazimo u postmodernizmu. Jedina konstruktivistička sila ovdje jesu materijalni uvjeti, što neminovno vodi podčinjavanju različitosti ženske obespravljenosti klasnoj borbi. Upravo zbog takvog reduciranog poimanja konstruktivizma kod Marxa, smatramo da su paralele koje Hartsock (1997) i Hekman (1997) povlače između shvaćanja subjekta kod Marxa i Foucaulta neodržive te da je Marxa ispravnije shvaćati kao klasič- 
nog teoretičara moderniteta. Naime, u njegovoj koncepciji i kapitalizam predstavlja tek pripremu za bolje društvo, pri čemu se očekuje da će se pojedinci, uslijed kontradikcija kapitalističkog sistema, konačno osloboditi pripisanih identiteta i utemeljiti nove društvene odnose na univerzalnim ljudskim vrijednostima (Mesić, 2006:47-53). Također, ako ostanemo u okviru Marxova rada, zanemarujući između ostalog i neomarksističke doprinose, shvaćanje moći ograničava se na patrijarhalni državni aparat, čime se našoj analizi umanjuje eksplanatorna snaga ,jer je Država, i sa svojom svemoći, i sa svojim aparatima, jako daleko od toga da prekrije čitavo realno polje odnosa moći; a zatim zato što Država ne može funkcionirati do li na osnovi ranije postojećih odnosa moći“ (Foucault, 1994c:153). Naravno, ovdje se ne zalažemo za napuštanje Marxova nasljeđa, već naglašavamo važnost novijih teorijskih pravaca koji nam otkrivaju ono skriveno ispod prosvjetiteljske univerzalnosti. U ovom kontekstu, posebno je produktivno istaknuti doprinose postmoderne teorije shvaćanju subjekta i identiteta koji nam omogućuju potpunije proučavanje različitih ženskih iskustava.

\section{POLITIČKE MOGUĆNOSTI POSTMODERNE FEMINISTIČKE TEORIJE STAJALIŠTA}

\subsection{Subjekt postmoderne feminističke teorije stajališta}

Uvriježeno je mišljenje kako predstavnička politika prvenstveno iziskuje „čvrstog“ subjekta čiji se interesi predstavljaju u političkoj areni. Navedenog uvjerenja nije lišena ni feministička teorija stajališta u okviru koje se neprestano postavlja zahtjev za održavanjem barem minimalnog subjekta žene. Naime, shvaća se kako ispod svih razlika među ženama ipak postoji nešto zajedničko, žensko, što omogućuje feminističku politiku, spašavajući žene od neminovnog utapanja u beskrajnim razlikama na kojima inzistira postmodernizam. Ovdje se vraćamo Harding (1987a:189) koja analizirajući zahtjev postmodernih kritičara za zajedništvom u emancipaciji tvrdi: „ali preuranjeno je za žene da budu voljne odustati od onog što nikad nisu imale. Trebaju li žene - bez obzira koje rase, klase ili kulture - smatrati razumnim odustati od želje da spoznaju i razumiju svijet sa stajališta njihovih iskustava po prvi put?"“. Drugim riječima, pita se nije li razumno inzistirati na političkom subjektu žene pa makar i pod cijenu ignoriranja različitosti žena. Međutim, autorica niti ne primjećuje kako uslijed navedene bojazni od postmodernizma širom otvara vrata esencijalizmu u feminističkoj teoriji. Naime, smatramo kako nije moguće, tek napominjući „bez obzira koje rase, klase ili kulture“, naprosto isključiti različitosti, stavljajući ih u zagradu, te se zatim posvetiti rodu kao izdvojenoj kategoriji. Upravo suprotno, ne vidimo kako se može izlučiti „čisti“ identitet, esenciju žene, iz rasnih, klasnih ili kulturnih odnosa u okviru kojih se rod neprestano izvodi. Štoviše, takvu potragu za istinskim identitetom ne smatramo vrijednom nastavljanja. Međutim, autoričino zazivanje subjekta treba shvatiti u kontekstu njene tvrdnje kako iz perspektive nekih postmodernih teoretičara "nikada ne može biti feminističke znanosti, sociologije, antropologije ili epistemologije, već samo mnoge priče koje različite žene 
pričaju o različitom znanju koje imaju“ (Harding, 1987a:188). Čini nam se kako postmodernizam u takvom shvaćanju predstavlja kritiku koja onemogućuje feminizam, rastvarajući ga naglašavanjem razlika među ženama. Međutim, u okviru postmodernog feminizma teži se izbjegavanju perpetuiranja pravila igre patrijarhalne predstavničke politike. Naime, shvaća se kako nekritično zahtijevanje „čvrstog“ subjekta žene zapravo onemogućuje predstavničku politiku jer se uspostavlja na isključivanju niza različitosti. Također, postmoderna kritika ne smjera grandioznom cilju trenutačnog odbacivanja predstavničke politike, već ističe potrebu kritičke genealogije praksi koje legitimiraju postojeće odnose moći (Butler, 2000:20-21). Svejedno, kritičarke postmodernizma bi se mogle složiti s Hartsock (1990:19) i reći da postmoderne teorije „ne uspijevaju pružiti temelje za alternativna i emancipatornija shvaćanja subjektiviteta" te ih stoga nema smisla predstavljati kao korisne za političke implikacije postmoderne teorije stajališta. Međutim, takva bi ocjena previdjela napore brojnih postmodernih teoretičarki, posebice Chantal Mouffe (1993:88), koja jasno ističe da „kritika esencijalizma i svih njegovih različitih oblika - humanizma, racionalizma, univerzalizma - daleko od bivanja preprekom stvaranja feminističkog demokratskog projekta, zaista je sam uvjet njegove mogućnosti“. U ovakvoj se koncepciji politike dokida potraga za esencijom, a nastoji utvrditi koji diskursi utječu na konstrukciju patrijarhalnog poimanja žene. Subjekt se proučava kao svojevrsno utjelovljenje niza subjektnih pozicija, konstituiran različitim diskursima, ali nikada u potpunosti „učvršćen“, već uvijek u procesu izvedbe identiteta (Mouffe, 1993:76-78). Međutim, važno je napomenuti da diskurzivna konstituiranost subjekta ne znači da je subjekt lišen svake odgovornosti i onemogućen u vlastitom djelovanju. Naime, subjekt nije determiniran diskursom te stoga nema potrebe za zazivanjem različitih preddiskurzivnih uporišta kako bi se politika omogućila. Upravo suprotno, shvaćanje da nema „čvrstog “ subjekta s pripadajućim interesima koji se sukladno tome predstavljaju, omogućuje uvođenje drugačijeg shvaćanja politike (Butler, 2000:143-149). U takvom, redefiniranom razumijevanju politike, feminizam ne predstavlja izdvojenu politiku, već se smješta u širi kontekst društva, pri čemu teži „transformaciji svih diskursa, praksi i društvenih odnosa gdje je kategorija 'žena' konstruirana na način koji implicira podređenost" (Mouffe, 1993:87-88). Dakle, napušta se ideja o postizanju jednakosti za žene kao empirijsku grupu koju karakterizira zajednička esencija. Međutim, navedeno ne znači dokidanje feminističke politike, već zahtijeva njeno širenje kako bi se eksplicirali i dokinuli diskursi koji perpetuiraju obespravljenost žena. Također, prihvaća se supostojanje mnoštva feminističkih politika, a potraga za istinskom feminističkom politikom odbacuje, budući da se ciljevi feminističke politike mogu uokviriti različitim diskursima (Mouffe, 1993:87-88). No, najvažnija značajka postmodernog feminizma za teoriju feminističkog stajališta jest postavljanje zahtjeva prema kojem „teorija mora biti eksplicitno historijska, prilagođena kulturnoj specifičnosti različitih društava i razdoblja te specifičnosti različitih skupina" (Fraser i Nicholson, 1999:35). Sukladno tome, napušta se i mogućnost univerzalnog političkog rješenja primjenjivog neovisno o kontekstu partikularnih problema. Feministice koje zastupaju ideju o univerzalnom rješenju za obespravljenost svih žena Gayatri Spivak (2011:74) smješta u kategoriju „feministič- 
kog ženskog aparatčika u stilu UN-a“, osvrćući se na globalnu primjenu lokalne borbe protiv patrijarhata. Dakle, prema navedenom shvaćanju politike, zadaća postmoderne feminističke teorije jest izgradnja lokaliziranih političkih solucija, pri čemu se posebna pozornost mora obratiti na eluzivni kontekst primjene osmišljenih mjera. Također, ovo epistemološko stajalište izgrađuje se na punini različitosti ženskih iskustava te je stoga za očekivati kako će potreba smještenosti politike biti shvaćena kao nužni uvjet svake emancipacije. Možda navedeno poimanje feminističke politike ne ostavlja impresivni dojam velikih feminističkih teorija, ali je u skladu s postojećim društvenim odnosima te ne iziskuje, svjesno ili nesvjesno, zanemarivanje razlika među ženama, odnosno „brisanje“ dijela žena iz feminističkog diskursa.

Naravno, postmoderna politika zahtijeva i drugačije shvaćanje javne sfere društva. Međutim, ne radi se o odbacivanju podjele na javno i privatno, već o njenom preoblikovanju. Naime, svako pitanje se shvaća kao sukob privatne i javne sfere, budući da se priznaje njihova međuovisnost. Također, Mouffe (1993:18) ističe potrebu uspostavljanja hegemonije zasnovane na multipliciranju demokratskih procesa. No, takva hegemonija nikada ne može biti potpuna jer sukobi nikada neće nestati iz društva. $S$ druge strane, upravo sukobi iziskuju radikalno demokratsko društvo koje je u stanju do izvjesne mjere uskladiti različite interese društvenih aktera. Međutim, zaista novo u njenom shvaćanju politike jest naglašavanje potrebe za izgradnjom novog identiteta, pri čemu se teži „konstruirati 'mi' kao radikalno demokratske građane, kolektivni politički identitet" (Mouffe, 1993:84). Javna sfera prema Mouffe (1993:83-86) nije pluralizam egoističnih interesa, nego prije svega poligon za izgradnju zajedničkog političkog identiteta. Dakle, hegemonija demokracije nije mnoštvo subalternih protujavnosti koje prema Nancy Fraser (2002:291) tvore „paralelne diskurzivne arene gdje članovi podređenih društvenih grupa stvaraju i cirkuliraju protudiskurse", dok su odnosi u javnoj sferi prvenstveno natjecateljski. Naposljetku, nije riječ niti o savezništvu u kojem se ignoriraju razlike i uspostavlja novi, ali i dalje „čvrsti“ identitet. Navedeno se izbjegava na način da se „uspostavi lanac ekvivalencije između različitih demokratskih borbi kako bi se stvorila ekvivalentna artikulacija između zahtjeva žena, crnaca, radnika, gayeva i drugih" (Mouffe, 1993:77). Stvara se radikalno demokratski identitet, pri čemu se feminizam ne gubi iz slike, ali se osigurava da borba jednih ne ugrožava borbu drugih, primjerice da se radnička prava ne ostvaraju nauštrb prava žena. Sukladno navedenom, prilikom politiziranja postmoderne feminističke teorije stajališta treba imati na umu kako kritika esencijalizma treba biti popraćena paralelnim razvijanjem kolektivnog demokratskog identiteta, čime se jasno pokazuje da odbacivanje esencijalizma ne znači nužno i nemogućnost ikakvog identiteta (Mouffe, 1993:19, 84-87). Također, političke napore valja usmjeriti radikalnoj demokratizaciji društva, pri čemu se demokracija shvaća kao proces, a ne kao instant rješenje. Naime, poanta demokracije nije proglasiti državu demokratskom i zatim zaboraviti na demokratske vrijednosti, fetišizirajući puku formu. Za demokraciju je ključan svojevrsni procesualni karakter, gdje se neprestano promišljaju rješenja različitih sukoba, istovremeno izgrađujući identitet koji omogućuje zajedništvo u emancipaciji. Uzimajući u obzir iskustva koja proizlaze iz isprepletenosti osi obespravljenosti žena, postmoderna 
feministička teorija stajališta ocrtava kompleksnost suvremene demokracije multiplicirajući vlastite političke mogućnosti, pritom uvažavajući društvenu smještenost znanja i identiteta.

\subsection{Prema razumijevanju vlastite smještenosti: „,izdajnički identiteti“}

Postmoderna feministička teorija stajališta posebice je korisna upravo za propitivanje društvene smještenosti. Ključni doprinos navedenom predstavlja koncept „izdajničkih identiteta" (engl. traitorous identities) ${ }^{2}$ koji uvodi Harding (1991:268-295), pri čemu se kao cilj feminističke teorije stajališta prije svega shvaća razumijevanje vlastite pozicije. Naime, autorica primjećuje kako pojedinci svojevoljno mogu postati marginalni, iako njihov pripisani identitet nije sam po sebi marginalan. Primjerice, heteroseksualci mogu postati marginalni „ne odbacivanjem svoje heteroseksualnosti, nego odbacivanjem spontane svijesti stvorene njihovim heteroseksualnim iskustvom u heteroseksističkom svijetu. Ti ljudi ne misle 'kao lezbijke', budući da nisu lezbijke. Ali oni misle kao heteroseksualne osobe koje su učile iz lezbijskih analiza" (Harding, 1991:289). Dakle, heteroseksualci time ne postaju predstavnici lezbijki niti vrsni znalci koji lezbijkama objašnjavaju kako djelovati, već izdaju vlastiti identitet i uče od obespravljenih lezbijki kako bi vlastitu društvenu poziciju podvrgnuli kritici. Dakle, postmoderna feministička teorija ne smjera proučavanju obespravljenih žena da bi im se pokroviteljski ukazalo na put prema emancipaciji ili ih se uspješnije predstavilo u okviru liberalne demokracije. Upravo suprotno, ključno je razumjeti vlastitu smještenost pomoću uvida omogućenih epistemološkim stajalištem izgrađenim na kritičkoj analizi iskustava obespravljenih žena. Naravno, „postizanje izdajničkog identiteta ili društvene lokacije zahtijeva izvođenje teških i bolnih zadataka" (Harding, 1991:293), pri čemu smatramo da nikad nije moguće u potpunosti izdati pripisani identitet jer su pojedinci konstituirani kulturom u kojoj se nalaze. Međutim, neprestano nastojanje na izdaji privilegiranih identiteta, koliko god bilo neugodno, otvara nove kritičke prostore i započinje borbu sa strukturama moći koje perpetuiraju obespravljenost.

Međutim, smatramo da su potrebne određene izmjene u načinu na koji autorica shvaća „izdajničke identitete“. Naime, oni koji izdaju vlastite privilegirane identitete „postaju marginalni“ (Harding, 1991:289), pri čemu se ponovno otvara pitanje značenja margine u suvremenom društvu. Alison Bailey (2000) ističe da se uslijed takvog opisa nepravilno poistovjećuje status ,autsajdera iznutra“, kao osobe s neposrednim iskustvom života na margini, i izdajice, koji nema takvo iskustvo, ali svojim djelovanjem postaje marginaliziran u epistemološkom smislu. Međutim, podsjećamo da Harding (1991:124) smatra da žene, kako bi ostvarile „status“ „autsajdera iznutra“, ne moraju ispunjavati uvjet iskustva života na prostorno određenoj margini. No, ne određuje marginu jednoznačno, a ni

2 „Izdajničke identitete“ ubrajamo u postmoderne doprinose, a i Harding (1991:295) ističe povezanost „izdajničkih identiteta“ i postmodernizma, pri čemu, nažalost, ne navodi vlastite izvore. 
sami ne vidimo kako bi se margina danas mogla definirati. Stoga smatramo hvalevrijednim poticaj na odbacivanje terminologije centra i margine kojeg nudi Bailey (2000), budući da naprosto nije korisna za analizu postojećih odnosa moći. Sukladno njezinom prijedlogu, a u okviru terminologije diskursa, izdajnike možemo shvatiti kao osobe koje su svjesne svojih privilegija te teže izmijeniti diskurs koji im omogućuje privilegiranost na štetu drugih. S druge strane, osobe koje nisu kritične naspram vlastitog privilegiranog položaja možemo razumjeti kao one koje perpetuiraju dominantni diskurs, u manjem ili većem stupnju. Naravno, razlika nije kategorijalna, a izdajica nije onaj koji tek povremeno počini izdajničko djelo, već osoba koja se neprestano trudi živjeti izdajnički te propitivati vlastitu smještenost s ciljem dokidanja obespravljenosti. Dodatni doprinos ove kritike pronalazimo u naglašavanju izdajničke performativnosti, pri čemu se pozornost usmjerava na kontinuirano izvođenje izdajničkih djela, a ne na „čvrsti“ izdajnički identitet. Dakle, nema jednostavne formule pomoću koje se postaje izdajica, već se radi o procesu koji zahtijeva neprestano obnavljanje i ovisi o kontekstu. Stoga postmodernu feminističku teoriju stajališta treba shvatiti kao izvor izdajničkih činova koji uvode nered u neometano obnavljanje diskursa koji omogućuju obespravljenost žena.

\section{AFERA SOKAL}

Prije nego što zaključimo ovaj rad, nije naodmet upustiti se u digresiju i razmotriti takozvanu „aferu Sokal“ (engl. Sokal affair) ${ }^{3}$ koja, po našem mišljenju, predstavlja jedan od važnijih uzroka olakog odbacivanja postmodernizma. Iako navedena afera ne problematizira feminističku teoriju stajališta, smatramo kako može imati neizravan utjecaj na status njenih postmodernih tendencija. Naime, diskvalifikacijom postmodernizma postaju upitne i mogućnosti postmoderne feminističke epistemologije te je stoga važno znati što ova afera označava.

Ukratko, fizičar Alan Sokal je 1996. godine poslao uredništvu znanstvenog časopisa Social Text rad pod nazivom Prelaženje granica: prema transformacijskoj hermeneutici kvantne gravitacije $e^{4}$, nakon čega je isti i objavljen. Međutim, u časopisu, koji se između ostalog bavi i postmodernizmom, nije primijećeno da je cilj Sokalova rada bio izrugati postmodernu teoriju. Naime, Sokal koristi koncepte razvijene u okviru prirodnih znanosti kako bi opravdao određene postmoderne postavke. No, namjerno ih u potpunosti pogrešno koristi, što nakon objave rada i sam priznaje, a sve kako bi pokazao da su postmodernisti prije svega „pomodne neznalice“. Nakon inicijalne afere, Sokal u suradnji s fizičarom Jeanom Bricmontom objavljuje knjigu Pomodna besmislica: postmoderni intelektualci iskoristavaju znanost ${ }^{5}$ te samostalno knjigu Iznad prijevare: znanost, filozofija

\footnotetext{
3 Poznata i kao Social Text affair i Sokal-Social Text affair.

4 Izvorno: Transgressing the boundaries: toward a transformative hermeneutics of quantum gravity, dostupno u Bricmont i Sokal (1998).

5 Izvorno: Impostures intellectuelles (engl. Fashionable nonsense. Postmodern intellectual's abuse of science) (1998).
} 
$i$ kultura $^{6}$, čime osigurava neprestanu revitalizaciju afere. Ovdje još treba spomenuti biologa Richarda Dawkinsa kao vatrenog zagovornika Sokalova rada, a vlastitim osvrtima i dosljednog nastavljača ove vrste diskvalifikacije postmodernizma.

Nalazimo više problema u Sokalovom pristupu. Prije svega Bricmont i Sokal (1998:7) i sami priznaju: „podrazumijeva se da mi nismo kompetentni suditi o neznanstvenim aspektima radova ovih autora". Misle pri tome na niz autora koje analiziraju, među kojima posebno istaknuto mjesto zauzimaju Jacques Lacan, Julia Kristeva, Luce Irigaray, Bruno Latour, Jean Baudrillard, Gilles Deleuze, Félix Guattari i Paul Virilio. Stoga se, prema vlastitim riječima, ograničavaju na tvrdnje postmodernih teoretičara povezanih $s$ konceptima iz matematike i fizike. $S$ druge strane, ne smatraju problematičnim označiti cijeli postmodernizam kao „nebulozan Zeitgeist“ (Bricmont i Sokal, 1998:4) na temelju analize manjeg dijela opusa navedenih autora. Također, Dawkins (2005:61) tvrdi da „nedvojbeno postoje neke misli tako dubokoumne da većina nas ne razumije jezik kojim su izražene“, ali ga to ne sprječava da postmoderniste okarakterizira kao „etablirane prazne balone“ (Dawkins, 2005:64). Drugim riječima, Bricmont, Dawkins i Sokal ne osjećaju se kompetentnima govoriti o neznanstvenim aspektima rada autora koje izučavaju, ali nemaju problema s diskvalifikacijom istih ako im se učini da postmoderni teoretičari pogrešno koriste koncepte iz prirodnih znanosti. Neovisno o sadržaju kritike postmodernog korištenja navedenih koncepata, ovdje se radi o nedopustivoj generalizaciji. Također, iščitavamo i veliku dozu pokroviteljskog stava prema kojem se tobože neozbiljne, „meke“ humanističke discipline trebaju ugledati na ozbiljne, „tvrde“ prirodne znanosti. Navedeno se najbolje vidi kada Dawkins (2005:67) ističe da su se Bricmont i Sokal ujedinili s kolegama iz prirodnih znanosti (naravno, nesklonih postmodernizmu) kako bi društvenim studijama i humanističkim disciplinama pružili „dobrohotno i blagonaklono vodstvo iz svijeta znanosti“. Međutim, Sokal (2010:457) ne staje na mesijanskoj ulozi, već postmoderniste, uz spin doktore i propagandiste, smatra neetičnima, budući da „ne brinu o razlici između onog što je istinito i što je lažno“, još jednom pokazujući vlastito nerazumijevanje postmodernizma. ${ }^{7}$

Slažemo se sa Žižekom (2001) koji tvrdi da kritika postmodernizma u okviru afere Sokal zapravo predstavlja pojednostavljen i karikaturalan prikaz postmoderne teorije. Tako čitamo da su radovi postmodernih teoretičara „manifestni slučajevi šarlatanstva“ čiji su autori „opijeni riječima kombiniranim s veličanstvenom indiferentnošću prema njihovom značenju" pa eventualno nerazumijevanje njihovih djela ne treba nikako pripisivati vlastitoj neupućenosti, budući da ti tekstovi „znače točno ništa“ (Bricmont i Sokal, 1998:5-6). Štoviše, postmoderni je francuski filozof prema Dawkinsu (2005:59) „intelektualni prevarant koji nema što reći“, a između ostalog ,isprazno laprda kao varalica i šarlatan“" (Dawkins, 2005:61). Zaista, čini nam se da ovakve karakterizacije nisu mnogo

6 Izvorno: Beyond the hoax. Science, philosophy and culture (2010).

7 Ovdje podsjećamo na riječi Foucaulta (1994a:164): „ono što pokušavam učiniti jest povijest odnosa koje mišljenje uspostavlja spram istine; povijest mišljenja kao mišljenja o istini. Svi oni koji kažu da za mene istina ne postoji jednostrani su duhovi“. 
više od banalnih stereotipa, namijenjene dokidanju postmodernizma kao jednoznačne kategorije. Svejedno, napominje Žižek (2001), cijela afera služi kao podsjetnik da se jasno mora razgraničiti postmoderna teorija od različitih pokušaja njene imitacije. Također, Derrida (2005) smatra kako je potrebno proučavati ulogu korištenja znanstvenih koncepata u postmodernizmu, ali uz obuhvatnije izučavanje niza zahtjevnih diskursa. Dakle, ne zalažemo se za izuzimanje postmodernih autora od kritike. Upravo suprotno, tražimo kritiku kako bi se prijeporna mjesta razjasnila, ali u konstruktivnom dijalogu, što nažalost nije bio cilj navedene afere.

\section{ZAKLJUČAK}

Ovim smo radom pokazali da postmoderne tendencije feminističke teorije stajališta predstavljaju izniman doprinos mogućnostima ove epistemologije. Radikalna budućnost feminističkog empirizma, koji uvodi žene u znanstveni diskurs, ispoljava se upravo u feminističkoj teoriji stajališta pri čemu su ženska iskustva napokon prepoznata kao vrijedan epistemološki resurs. Također, ne radi se o pukom „dodavanju“ žena u istraživanja, već o polasku od iskustava obespravljenih žena kako bi se izgradilo feminističko stajalište. Postmodernizam omogućuje feminističkoj epistemologiji razvitak bez ikakvog zazivanja bioloških temelja rodnih razlika i preddiskurzivnih karakteristika ženskih iskustava. Jednostavno, postmoderna feministička stajališta treba shvatiti kao izvorišta diskursa, uglavnom protuhegemonijskih, pri čemu valja obratiti pozornost na razlomljenu i kontradiktornu narav diskursa. Također, ako se prihvati diskurzivna strukturiranost stvarnosti, obustavlja se potraga za materijalnom stvarnošću „očišćenom“ od diskursa. Međutim, otvara se potraga za svim diskursima koji omogućuju obespravljenost žena, pri čemu cilj feminizma postaje njihova transformacija i dokidanje. No, postmodernizam uvodi i drugačiju konceptualizaciju subjekta. Odbacivanje esencijalizma postaje uvjet feminističke politike, a kada se odlučno prekine s esencijaliziranjem rodnih odnosa nestaje i „čvrsti“ subjekt žene kojeg iziskuje tradicija predstavničke demokracije. Sukladno tome, na njegovo mjesto dolazi shvaćanje subjekta konstituiranog mnoštvom diskursa i neprestano u procesu nastajanja identiteta, lišenog esencije iz koje navodno proizlaze njegovi interesi. Međutim, u okviru postmoderne feminističke politike ističe se potreba izgradnje kolektivnog političkog, radikalno demokratskog identiteta, što nadilazi jednostavno odbacivanje esencijalizma i razotkriva manjkavost kritike prema kojoj postmodernizam vodi u potpunu nemogućnost identiteta. Također, teži se hegemoniji demokratskih vrijednosti, a prilikom političkog djelovanja inzistira se na važnosti konteksta i lokaliziranosti rješenja, shvaćajući kako ne postoje univerzalno primjenjivi politički recepti. No, još važnije, stajalište se ne izgrađuje kako bi se obespravljenim ženama dijelilo pokroviteljske savjete s pozicije intelektualaca koji djeluju u liberalnim društvima, tobože utemeljenim na razumu. Također, ne želi se zauzimati uloga elokventnih glasnogovornika obespravljenih. Glavni cilj postmoderne feminističke teorije stajališta jest razumijevanje vlastite društvene smještenosti, njena bespoštedna kritika te eliminiranje struktura moći koje omogućuju obespravljenost žena. Naravno, navedeno 
postaje posebice nelagodno kada se shvati da su vlastita društvena smještenost i strukture koje vode obespravljenosti vrlo često isprepleteni. Takav pristup politici zahtijeva napore prema izdaji privilegija stečenih na račun obespravljenih osoba, što se zbog konstitutivne uloge kulture ne može postići tako da se vlastita privilegiranost jednostavno „odreže“, već opetovanim „izdajničkim činovima“ pomoću kojih se postupno mijenjaju postojeći odnosi moći.

\section{LITERATURA}

Bailey, A. (2000). Locating Traitorous Identities: Toward a View of Privilege-Cognizant White Character. U: Harding, S. i Narayan, U. (ur.), Decentering the Center: Philosophy for a Multicultural, Postcolonial, and Feminist World (str. 283-298). Bloomington, IN: Indiana University Press.

Bell, D. (2007). Cyberculture Theorists: Manuel Castells and Donna Haraway. London: Routledge.

bell hooks. (1990). Yearning: Race, Gender, and Cultural Politics. Boston, MA: South End Press.

Bricmont, J. i Sokal, A. (1998). Fashionable Nonsense. Postmodern Untellectuals' Abuse of Science. New York, NY: Picador.

Butler, J. (2000). Nevolje s rodom. Feminizam i subverzija identiteta. Zagreb: Ženska infoteka.

Campbell, K. (2004). The Promise of Feminist Reflexivities: Developing Donna Haraway's Project for Feminist Science Studies. Hypatia, 19(1): 162-182.

Collins, P. H. (2004). Learning from the Outsider Within: The Sociological Significance of Black Feminist Thought. U: Harding, S. (ur.), The Feminist Standpoint Theory Reader. Intellectual and Political Controversies (str. 103-126). London: Routledge.

Dawkins, R. (2005). Vragov kapelan. Razmišljanja o nadi, lažima, znanosti i ljubavi. Zagreb: Jesenski i Turk.

Derrida, J. (2005). Paper Machine. Stanford, CA: Stanford University Press.

Foucault, M. (1994a). Briga za istinu. U: Kalanj, R. (ur.) Znanje i moć (str. 163-172). Zagreb: Globus.

Foucault, M. (1994b). Mehanizmi seksualnosti. U: Kalanj, R. (ur.), Znanje i moć (str. 55-91). Zagreb: Globus.

Foucault, M. (1994c). Mikrofizika moći. U: Kalanj, R. (ur.), Znanje i moć (str. 143162). Zagreb: Globus.

Fraser, N. (2002). Politics, Culture, and the Public Sphere: Toward a Postmodern Conception. U: Nicholson, L. i Seidman, S. (ur.), Social Postmodernism: Beyond Identity Politics (str. 287-312). Cambridge: Cambridge University Press.

Fraser, N. i Nicholson, L. J. (1999). Društvena kritika bez filozofije: susret feminizma i postmodernizma. U: Nicholson, L. J. (ur.), Feminizam / postmodernizam (str. 2338). Zagreb: Liberata. 
Haraway, D. (1988). Situated Knowledges: The Science Question in Feminism and the Privilege of Partial Perspective. Feminist Studies, 14(3): 575-599.

Harding, S. (1987a). Conclusion. Epistemological questions. U: Harding, S. (ur.), Feminism and Methodology (str. 181-190). Bloomington, IN: Indiana University Press.

Harding, S. (1987b). Introduction: Is there a Feminist Method? U: Harding, S. (ur.), Feminism and Methodology (str. 1-14). Bloomington, IN: Indiana University Press.

Harding, S. (1991). Whose Science? Whose Knowledge? Thinking from Women's Lives. Ithaca: Cornell University Press.

Harding, S. (1999). Feminizam, znanost i kritike prosvjetiteljstva. U: Nicholson, L. J. (ur.), Feminizam / postmodernizam (str. 76-90). Zagreb: Liberata.

Harding, S. (2004). Rethinking Standpoint Epistemology: What is 'Strong Objectivity'? U: Harding, S. (ur.) The Feminist Standpoint Theory Reader. Intellectual and Political Controversies (str. 1-16). London: Routledge.

Hartsock, N. C. M. (1990). Postmodernism and Political Change: Issues for Feminist Theory. The Construction of Gender and Modes of Social Division II, 14: 15-33.

Hartsock, N. C. M. (1997). Comment on Hekman's "Truth and Method: Feminist Standpoint Theory Revisited”: Truth or Justice? Signs, 22(2): 367-374.

Hartsock, N. C. M. (2004). The Feminist Standpoint: Developing the Ground for a Specifically Feminist Historical Materialism. U: Harding, S. i Hintikka, M. B. (ur.), Discovering Reality. Feminist Perspectives on Epistemology, Metaphysics, Methodology, and Philosophy of Science (str. 35-53). Boston, MA: Kluwer Academic Publishers.

Hekman, S. (1997). Truth and Method: Feminist Standpoint Theory Revisited. Signs, 22(2): 341-365.

Hirschmann, N. J. (2004). Feminist Standpoint as Postmodern Strategy. U: Harding, S. (ur.), The Feminist Standpoint Theory Reader. Intellectual and Political Controversies (str. 317-332). London: Routledge.

Jäger, S. (2001). Discourse and Knowledge: Theoretical and Methodological Aspects of a Critical Discourse and Dispositive Analysis. U: Meyer, M. i Wodak, R. (ur.), Methods of Critical Discourse Analysis (str. 32-62). London: SAGE Publications.

Mesić, M. (2006). Multikulturalizam. Zagreb: Školska Knjiga.

Mouffe, C. (1993). The Return of the Political. London: Verso.

Ruddick, S. (1995). Maternal Thinking. Toward a Politics of Peace. Boston: Beacon Press.

Smith, D. E. (1997). Comment on Hekman's “Truth and Method: Feminist Standpoint Theory Revisited". Signs, 22(2): 392-398.

Smith, D. E. (2004). Women's Perspective as a Radical Critique of Sociology. U: Harding, S. (ur.), The Feminist Standpoint Theory Reader. Intellectual and Political Controversies (str. 21-33). London: Routledge.

Sokal, A. (2010). Beyond the Hoax. Science, Philosophy and Culture. Oxford: Oxford University Press.

Spivak, G. C. (2011). Mogu li podčinjeni [subaltern] govoriti? U: Spivak, G. C. (ur.) Nacionalizam i imaginacija: I drugi eseji (str. 65-162). Zaprešić: Fraktura.

Weedon, C. (1987). Feminist Practice and Poststructuralist Theory. Oxford: Blackwell. 
Žižek, S. (2001). The Fright of Real Tears. Krzysztof Kieślowski Between Theory and PostTheory. London: British Film Institute. 


\title{
FEMINIST EPISTEMOLOGY: POSSIBILITIES OF POSTMODERN FEMINIST STANDPOINT THEORY
}

\author{
Matko Krce-Ivančić
}

\begin{abstract}
This article explores the possibilities of postmodern feminist standpoint theory as being one of the more prominent feminist epistemologies. The context of this epistemology is introduced, while stressing the importance of establishing a classification offeminist epistemologies that recognizes postmodernism as a key part of feminist empiricism and feminist standpoint theory. Analyses of the essential themes of feminist standpoint theory are undertaken from the postmodern perspective, emphasizing the discursive nature of social reality. We examine the political possibilities of this epistemology, indicating the need for a different conceptualization of the political subject. The subject is understood as constituted, rather than determined, by discourse. Bearing this in mind, we question the importance of retaining various prediscursive foundations of feminist politics. We consider a postmodern feminist standpoint to be a specific type of discourse, while underscoring the deficiency of distinguishing between discourse and material reality. Understanding our social situatedness is identified as a main goal of postmodern feminist standpoint theory.
\end{abstract}

Keywords: epistemology, feminism, postmodernism, situatedness, feminist standpoint theory

\section{FEMINISTISCHE EPISTEMOLOGIE: MÖGLICHKEITEN EINER POSTMODERNEN FEMINISTISCHEN STANDPUNKTTHEORIE}

\author{
Matko Krce-Ivančić
}

\section{Zusammenfassung}

Dieser Artikel setzt sich mit den Möglichkeiten der postmodernen feministischen Standpunkttheorie als eine der prominenteren feministischen Epistemologien auseinander. Wir bringen den Kontext dieser Epistemologie hervor und betonen die Wichtigkeit der Herstellung einer Klassifizierung feministischer Epistemologien, die den Postmodernismus als einen integralen Teil des feministischen Empirismus und der feministischen Standpunkttheorie erkennt. Wir analiysieren die Grundthesen der feministischen Standpunkttheorie aus der postmodernen Perspektive und betonen die diskursive Natur der sozialen Wirklichkeit. Wir erforschen politische Möglichkeiten dieser Epistemologie, indem wir auf die Notwendigkeit eines andersartigen Verstehens des politischen Subjektes hinweisen. Das Subjekt verstehen wir als durch den Diskurs konstituiert, aber nicht determiniert. Deshalb erörtern wir die Wichtigkeit des Erhaltens verschiedener vordiskursiven Stützpunkte der feministischen Politik. Den postmodernen feministischen Standpunkt verstehen wir als eine bestimmte Art des Diskurses, wobei wir die Unzulänglichkeit des Unterscheidens zwischen dem Diskurs und der meteriellen Wirklichkeit hervorheben. Das Verständnis der eigenen sozialen Situiertheit identifizieren wir als das Hauptziel der postmodernen feministischen Standpunkttheorie.

Schlüsselwörter: Epistemologie, Feminismus, Postmodernismus, Situiertheit, feministischen Standpunkttheorie 